\title{
In Pursuit of Sustainable Strategic Long-term Planning Throughout Meta-postmodernism as New Perspective of Stylistic Design
}

\author{
* Ph.D. Candidate Mojdeh Nikoofam ', Ph.D. Candidate Abdollah Mobaraki ${ }^{2}$ \\ 1 Department of Architecture, Faculty of Architecture, Eastern Mediterranean University, Turkey \\ 2 Department of Architecture, Faculty of Fine Arts, Design and Architecture, Cyprus international University, Turkey \\ E mail: mojdeh.nikoofam@gmail.com ,E mail: a_mobarakie@yahoo.com
}

\section{A R T I C LE I N F O: \\ Article history: \\ Received 1 December 2016 \\ Received in revised form 30 \\ December 2016 \\ Accepted 30 January 2017 \\ Available online 2 January \\ 2017 \\ Keywords: \\ Meta-postmodernism; \\ Long-term planning; \\ Sustainability; \\ Quality of life.}

This work is licensed under a Creative Commons Attribution

NonCommercial - NoDerivs 4.0. "CC-BY-NC-ND"

\begin{abstract}
A B S T R A C T
During the different period of architectural design, designers attempt to achieve high level of life quality for all users. Architecture and urban planner want to provide a style of design which not only achieves different function for different users with respect to their ethnicity, ability, age, sex, capability, position, and life style but also improve friendly environment throughout responsive legislation based on long-term planning. Although, the styles are considered some indicators, it is ignored the other important characteristics. Therefore, the existing styles never achieve standard level of satisfaction of different people. The goal of the research is to introduce metapostmodern style as supplement stylistic approach. The style tries to consider all important indicators that create a strategic long-term planning for different generations. Various characteristics of new style can be applied to improve the quality of human life and provide a health, livable and sustainable planning for all users.

JOURNAL OF CONTEMPORARY URBAN AFFAIRS (2017) 1 (1), 45-55.

https://doi.org/10.25034/1761.1(1)45-55
\end{abstract}

WWw.ijcua.com

Copyright @ 2017 Journal Of Contemporary Urban Affairs. All rights reserved.

\section{Introduction}

During the last decade, most of cities have created the common problems for nations and future generation. Ozay (2005) mentioned cities always are the heart of civilization and vitality. Designers are able to reflect civilization by considering cultural, environmental, economic, social and technological characteristics of the society. Architecture is a combination of art and science for designing building and environment and it can give proper expression to the personalities and social status of people (Able, 1997). However, according to Heynen \& Henket (2002), industrial revolution invites our world to the new era that the revolution also has significant influence on the architectural trend. Modern style has arrived to design and architecture. New technology and high speed access to all sciences and knowledge are the major cause to change life perception as well as architecture design. Consequently, modern architecture was faced with controversial trend because this style had been ignored many characteristics which have deep effect

\footnotetext{
*Corresponding Author:

Department of Architecture, Faculty of Architecture, Eastern Mediterranean University, Gazimagusa, via Mersin 10, Turkey

E-mail address: mojdeh.nikoofam@gmail.com
} 
on quality of human life. Although, there are many benefits in being adapted with the progressive modern cities and building, the trend had been provided many problems during this blind imitation. Glassy high rise building and homogenized apartments was seen everywhere in the cities regardless environmental and cultural factors of the metropolitans. According to the disadvantages of the style, architecture and urban planning understand that their design should be considered all important values. So, postmodern style tried to make integration between past and present but the style caused many disadvantages like lack of diversity and consideration future people. Architecture and urban design are more than science or art. They can be defined a language that can reflect spiritual, social, cultural and environmental characters, national identity of a specific region by symbolic meaning, and prestige of structures. Design can have deep influence on various aspects that they contain: a) psychological, and health aspect of human; b) our natural, physical and built environment; c) social and cultural characteristic; d) cost of life; e) health and needs of future generation. Therefore, in the following context of the study have been attempted to introduce a new stylistic approach which based on long term vision in order to make sustainable future cities. The cities are designed based on strategic meta-postmodernism style to support high quality of human life for present and future people. Meanwhile, the style try to provide post nationality which is mean space and city not only sustain sense of place for their local people but also there are attractive and memorable for strange people. The graph is illustrated the structure of the study to consider the important indicator of design which have deep effect on improving the quality of life for all generation.

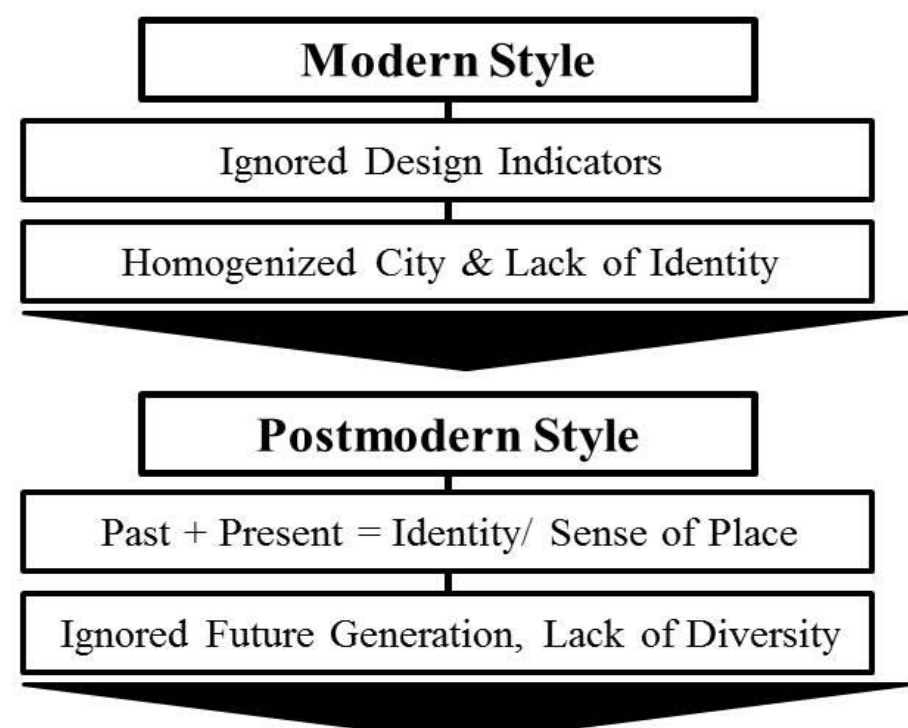

\section{Meta-postmodern Style}

Past + Present $($ Native and Strange $=$ Post-nationality $)+$ Future

\begin{tabular}{|c|c|c|}
\hline $\begin{array}{l}\text { Environmental/ } \\
\text { natural Factors }\end{array}$ & $\begin{array}{c}\text { Physical } \\
\text { Characteristics }\end{array}$ & $\begin{array}{c}\text { Cultural } \\
\text { Characteristics }\end{array}$ \\
\hline \multirow[t]{2}{*}{$\begin{array}{c}\text { Social } \\
\text { Characteristics }\end{array}$} & $\begin{array}{c}\text { Economic } \\
\text { Characteristics }\end{array}$ & $\begin{array}{l}\text { Technological } \\
\text { Innovation }\end{array}$ \\
\hline & $\begin{array}{c}\text { Political } \\
\text { Characteristics }\end{array}$ & \\
\hline
\end{tabular}

Fifure 1. Structure of the Study. 


\section{Modern Style}

Architecture and urban planning started to give up the traditional styles and start to create further form in constructions at the beginning of $20^{\text {th }}$ century with respecting to distribution Western modern architecture and from which underpinned many significant concerns in our world. After industrialization, the building was made more affordable and stronger by using new technology. The new technique created an opportunities for designer to construct wider spaces and taller building. Also, by using new technology, mass production of materials became easier and more inexpensive. In addition, the new methods increased the speed of construction process.

On the other hand, Morgan (1914) stated that the introduction of modern period organized fast urbanization and construction in cities. Therefore, more homogenized cities and continuity structure was appeared and the cultural, traditional and vernacular architecture was disappeared in designing. Because the architecture only accepted the modern style in their design and abandon the traditional styles without any consideration. It was the time to face with many disadvantages such as designer try to construct affordable building and public areas regardless considering climatic characteristic. In consequent, people should cost more but received less profits or efficient (Mokhtarshahi, 2009). Also, ignoring the climatic factors will enhance environmental pollution in long term that it is able to decrease the human health and more compromising life of future generation. Moreover, aesthetical characteristics are other crucial parameters in architectural design but the consideration was neglected in the built environment and constructions (Schoon, 1992). It is so clear that identity plays a significant role in civic life and individuals' culture however cities, spaces and building can't achieve sense of belonging for the users (Fig.1).

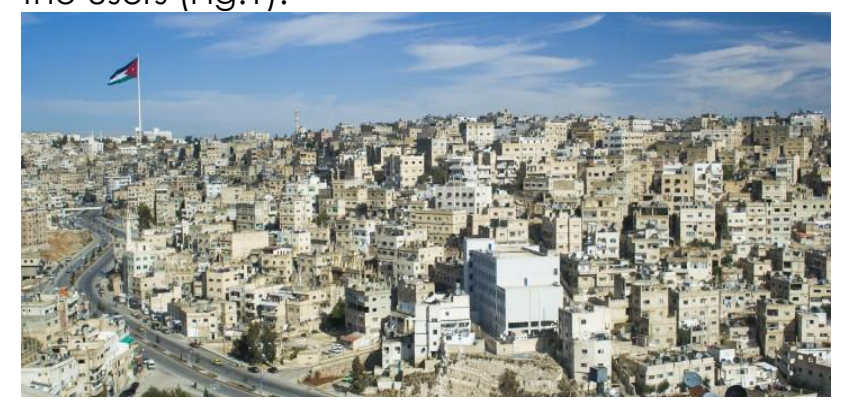

Figure 2. Homogenized Building Create an Ugly City and Lack of Sense of Place for Users (URL 1).

Thus, losing sense of place leaded to decrease social participation/ communication, safety and lack of identity increased social conflict, crime and transgressions in towns. According to advantages and disadvantage of this era of architectural design has been illustrated in Table 1. To sum up, designer tried to make integration between past and present so postmodernism style started to overcome the objectives of the designs.

\begin{tabular}{|c|c|}
\hline \multicolumn{2}{|c|}{ Distribution Modern Design } \\
\hline Advantage & Disadvantage \\
\hline 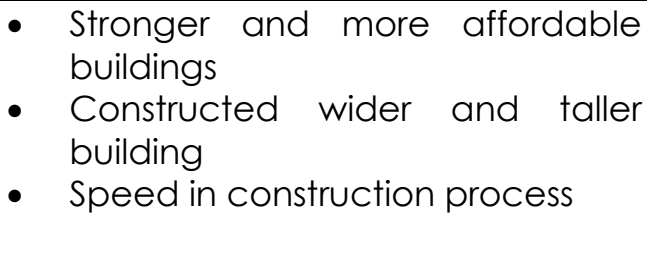 & $\begin{array}{l}\text { - } \quad \text { Continuity structure and homogenized cities } \\
\text { - } \quad \text { Disappear cultural \& traditional architecture } \\
\text { - } \quad \text { More cost and less proficient } \\
\text { - } \quad \text { Polluted environment } \\
\text { - } \quad \text { Insappear sense of belongingness } \\
\text { - Increase social problems and crime }\end{array}$ \\
\hline
\end{tabular}

Table 1. The advantage and disadvantage of Modern style.

\section{Postmodern Style}

As it is mentioned in previous section, city governors and architects attempt to re-survive city identity by applying post-modern style in architecture and urban forms (Harvey, 1989). Architecture understood that the structure should contain cultural and social values so they attempted to make integration between past and present. Cities should develop the sense of place in the built environment by applying human's culture and traditional indicators. The idea of post-modernism was applying urban process and constructions to increase livability throughout traditional environment. The style wants to increase local sense of place by embedding culture and regional architecture (Harvey, 1993). However, the style of design doesn't have long term 
vision so some important indicators are ignored such as future generation, the anticipated consequences like increase older population and some of the important human's requirements. Also, creativity and innovation gave up design through the postmodern style. Calinescu (1987) mentioned that the style is meaningless because it uses empirical knowledge. Lack of long term vision cause urban sprawl, lose wild life and agricultural ground, health communication, and social segregation in the cities. On one hand, designer focused on cultural and social activities by integrating past and present on the other hand they couldn't overcome objectives because of lack of strategic planning. In the study will be introduced a new approach to the new style in design based on make sustainable cities with making strategic harmony between past, present and future.

\section{New Stylistic Approach to the Sustainable Long-term Planning}

Sustainability is a global process to support an enduring future where environmental and social factors have a parallel process with economic dimensions (Newman, 2002). On the other hand sustainability is defined by the World Commission on Environment and Development (1987) that the present people can meet their own requirements without ignoring the needs of future population to meet their fundamental needs. The study carefully has improved all of the significant dimension in planning to define sustainable planning with increasing quality of life for future and current generation without compromising the sense of place for present people.

\subsection{Meta-postmodernism Style}

The new style tries to consider the significant characteristic of planning to create long term planning and develop greenery spaces, legibility, complexity, diversity, visual quality, personalization, accessibility, coherence, attractiveness, affordability, safety, comfort, cleanliness, inclusivity, adaptability, availability, and vitality in our environment. The style planning wants to increase health contribution, user satisfaction, various activities, infrastructure necessities, rise of sense of belonging or individual identity, and aesthetical perception for current and future generations. Therefore, the Meta-postmodern style means after postmodernism that the new approach focuses on environmental, physical, cultural, social, economic, technological and political dimensions which are defined in the following sections.

\subsection{1 environmental/natural characteristics}

Topography is the initial survey to indicate the general shape of the city or land which to identify suitable planning for the land such as drainage design for flat land or comfortable planning for steep land. Topography plan provide slope analysis to make advantages for the design (Beer, Higgins, 2000). The slope of land might be steep, moderate, and flat that an appropriate design can moderate hazard factors and take opportunities from this factor. Topography has deep influence on receiving suitable sun radiation and wind to increase comfortable temperature in public and private spaces of the city. Also, it can be exploited for achieving visual and sensory characteristics by creating aesthetical and recreational places. Moreover, the character can impact on suitable access and circulation for the users by a good planning.

Table 2 shows the relationship between the advantage of topography and the dimensional of sustainability.

\section{Topography}

$\begin{aligned} & \text { Visual and Sensory (health } \\
& \text { characteristics) }\end{aligned}$
\begin{tabular}{l|l|l|l|l|l|l|l|l}
\multicolumn{2}{l}{$\begin{array}{l}\text { Suitable sun radiation, wind and } \\
\text { drainage design (comfortable space } \\
\text { temperature) }\end{array}$} & $\begin{array}{l}\text { Access and com } \\
\text { (community) }\end{array}$ \\
\hline Environment & Social & Economic & Environment & Social & Economic & Environment & Social & Economic \\
\hline & $\sqrt{ }$ & $\sqrt{ }$ & $\sqrt{ }$ & & $\sqrt{ }$ & & $\sqrt{ }$ & $\sqrt{ }$ \\
\hline
\end{tabular}

Table 2. Integration between Topography Characteristics and Dimension of Sustainability.

Considering local climate is other important consideration to achieve comfortable outdoor and indoor spaces. The utilize local climate characteristics is not a contemporary innovation. Consideration of the data back to much many years ago that unfortunately it is ignored these days in our designing. Ignored local climate in designing has caused increase air pollution due to rise of $\mathrm{CO}^{2}$ emission, urban heat island, and decrease energy 
consumption. Our designing based on local climate could provide interior and exterior comfortable space; heating protection in different seasons and using solar energy for day lighting according to suitable orientation. The most significant factors in considering local climate are human comfort not only at outdoor spaces where is limited for air controlling also at indoor spaces for decreasing energy cost. Air movement, humidity and solar radiation are climatic factors to influence on human comfort (Beer, Higgins, 2000).

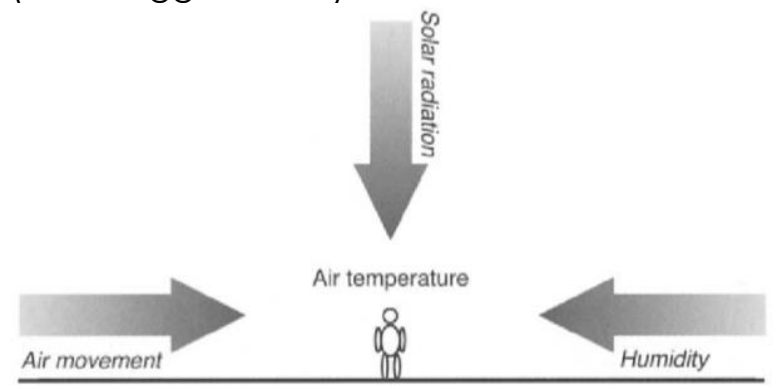

Figure 3. Climate Factors and Human Comfort (Beer, Higgins, 2000)

Suitable space or building orientation, receiving natural lighting, appropriate shading elements for cooling hot climate, decreasing air pollution are crucial factors which achieved by considering solar radiation. Air movement is measured by considering the speed of wind and prevailing wind which are important for decreasing hot temperature and air pollution. Measuring the annual rainfall can have deep effect on controlling humanity. Carful considering local climate characteristics in urban and building designing have deep influence to decrease air pollution, fuel energy consumption by achieving passive solar energy and cost of energy. Also, the data increase human comfort for outdoor activity and recreational spaces.

\begin{tabular}{|c|c|c|c|c|c|c|c|c|c|c|c|}
\hline \multicolumn{12}{|c|}{ Local Climate } \\
\hline \multicolumn{2}{|c|}{$\begin{array}{l}\text { Decrease } \\
\text { pollution, } \\
\text { heat island }\end{array}$} & $\begin{array}{l}\text { air } \\
\text { urban }\end{array}$ & \multicolumn{3}{|c|}{$\begin{array}{l}\text { Achieving passive } \\
\text { solar energy }\end{array}$} & \multicolumn{3}{|c|}{$\begin{array}{l}\text { Increase } \\
\text { recreational activity } \\
\text { in outdoor spaces }\end{array}$} & \multicolumn{3}{|c|}{$\begin{array}{l}\text { Decrease cost of } \\
\text { energy and fuel energy } \\
\text { consumption }\end{array}$} \\
\hline 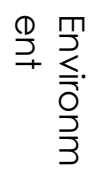 & $\begin{array}{l}\tilde{O} \\
\text { ก. } \\
\underline{\underline{0}} .\end{array}$ & $\begin{array}{l}\text { กั } \\
\text { กิ } \\
\frac{0}{2} \\
\frac{0}{3} \\
\frac{3}{n} .\end{array}$ & 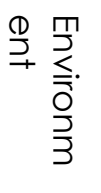 & $\begin{array}{l}\tilde{O} \\
\text { ก. } \\
\underline{\underline{0}}\end{array}$ & $\begin{array}{l}\text { ก1 } \\
\text { ก } \\
\frac{0}{3} \\
\frac{0}{3} \\
3 .\end{array}$ & 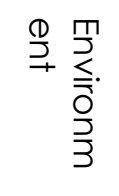 & $\begin{array}{l}\tilde{\Omega} \\
\text { ก. } \\
\underline{\underline{0}}\end{array}$ & $\begin{array}{l}\text { ח1 } \\
\text { } \\
\frac{0}{2} \\
\frac{0}{3} \\
3 .\end{array}$ & 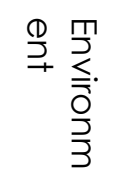 & $\begin{array}{l}\widetilde{c} \\
\text { ก. } \\
\underline{\underline{0}}\end{array}$ & $\begin{array}{l}\text { กூ } \\
\text { กิ } \\
\frac{0}{3} \\
\frac{0}{3} \\
\frac{3}{n} .\end{array}$ \\
\hline$\sqrt{ }$ & $\sqrt{ }$ & $\sqrt{ }$ & $\sqrt{ }$ & $\sqrt{ }$ & $\sqrt{ }$ & & $\sqrt{ }$ & $\sqrt{ }$ & $\sqrt{ }$ & $\sqrt{ }$ & $\sqrt{ }$ \\
\hline
\end{tabular}

Table 3. Integration between Local Climate Characteristics and Dimension of Sustainability

Vegetation, relative ecological value, biodiversity and wildlife are the significant information to have deep influence on energy consumption, air quality, and provision aesthetical consideration or urban morphology (Laurie, 1979). Plants and greenery properties can decrease the effect of hot temperature and control solar glare as shading elements. The natural properties on one hand has influence on humidity by providing air movement on the other hand can be utilized to control the speed of wind. Additionally, greenery area not only can provide the Oxygen which is necessary for human life but also decrease $\mathrm{CO}^{2}$ capacity in air which increases air quality and human health. Moreover, vegetation and biodiversity property achieve more health communities, urban vitality and aesthetical characteristics or visual quality as decorative elements in cities. It is so clear that noise pollution have deep effect on psychological people health that the greenery belt reduce noise level in building and build environment. Table 4 shows relationship between the natural indicators like plants, biodiversity, and wildlife properties with dimension of sustainability in order to increase quality of human life and their civic life. 


\begin{tabular}{|c|c|c|c|c|c|c|c|c|c|c|c|}
\hline \multicolumn{12}{|c|}{ Vegetation, Relative Ecological Value, Biodiversity and Wildlife } \\
\hline \multicolumn{3}{|c|}{$\begin{array}{l}\text { health communities, } \\
\text { urban vitality }\end{array}$} & \multicolumn{3}{|c|}{$\begin{array}{l}\text { Increase air quality } \\
\text { and decrease sound/ } \\
\text { air pollution }\end{array}$} & \multicolumn{3}{|c|}{$\begin{array}{l}\text { Energy consumption } \\
\text { (control air movement, } \\
\text { solar glare) }\end{array}$} & \multicolumn{3}{|c|}{$\begin{array}{l}\text { Visual and aesthetical } \\
\text { consideration (urban } \\
\text { morphology) }\end{array}$} \\
\hline \multirow[t]{2}{*}{ 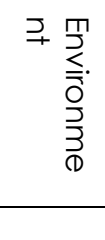 } & $\begin{array}{l}\widetilde{\Omega} \\
\text { ก. } \\
\underline{\underline{\alpha}}\end{array}$ & $\begin{array}{l}\text { m. } \\
\text { Oे } \\
\frac{0}{2} \\
\frac{0}{3} \\
\frac{n}{n}\end{array}$ & 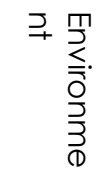 & $\begin{array}{l}\tilde{O} \\
\underline{\Omega} . \\
\underline{\underline{0}}\end{array}$ & $\begin{array}{l}\text { m. } \\
\text { Oे } \\
\text { Oे } \\
\frac{0}{3} \\
\frac{3}{n}\end{array}$ & 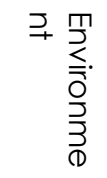 & $\begin{array}{l}\tilde{O} \\
\underline{\Omega} . \\
\underline{\underline{0}}\end{array}$ & 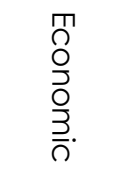 & 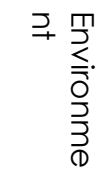 & $\begin{array}{l}\widetilde{\sim} \\
\text { ก. } \\
\underline{\underline{\underline{D}}}\end{array}$ & $\begin{array}{l}\text { ח1 } \\
\text { Oे } \\
\text { Oे } \\
\frac{0}{3} \\
\frac{3}{n}\end{array}$ \\
\hline & $\sqrt{ }$ & $\sqrt{ }$ & $\sqrt{ }$ & $\sqrt{ }$ & $\sqrt{ }$ & $\sqrt{ }$ & & $\sqrt{ }$ & & $\sqrt{ }$ & $\sqrt{ }$ \\
\hline
\end{tabular}

Table 4. Integration between Plants, Wildlife Properties and Dimension of Sustainability.

Soil and water quality are the other significant sources to improve plants, wildlife, ecological and biodiversity values which have deep influence on the quality of individual life. The soil information defines the bearing capacity of the site to provide suitable bed for growing different vegetation, agricultural productions, and land management practices. Conservation of water resources, greenery properties, natural habits, landscape characteristics, visual qualities will be provided by considering soil information (Courtney, Trudgill, 1984). Additionally, water quality provides fertile land for growing vegetation, shaping landscape, controlling flood. Moreover, water provides visual and aesthetical characteristics as well.

\begin{tabular}{|c|c|c|c|c|c|c|c|c|c|c|c|}
\hline \multicolumn{12}{|c|}{ Geology (Water, Soil) } \\
\hline \multicolumn{3}{|c|}{$\begin{array}{l}\text { Increase agricultural } \\
\text { land for providing food } \\
\text { requirement }\end{array}$} & \multicolumn{3}{|c|}{$\begin{array}{l}\text { Growing the quality of } \\
\text { vegetation, relative } \\
\text { ecological value, } \\
\text { biodiversity \& wildlife }\end{array}$} & \multicolumn{3}{|c|}{$\begin{array}{l}\text { Increasing water and } \\
\text { soil quality }\end{array}$} & \multicolumn{3}{|c|}{$\begin{array}{l}\text { Visual \& aesthetical } \\
\text { consideration (urban } \\
\text { morphology) }\end{array}$} \\
\hline 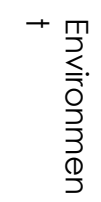 & $\begin{array}{l}\tilde{O} \\
\underline{\underline{\Lambda}} .\end{array}$ & $\begin{array}{l}\text { ח1 } \\
\text { Oे } \\
\frac{0}{2} \\
\frac{0}{3} \\
\frac{3}{n}\end{array}$ & 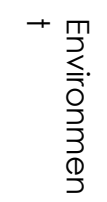 & $\begin{array}{l}\tilde{O} \\
\underline{ก} .\end{array}$ & 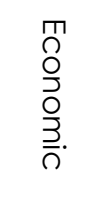 & 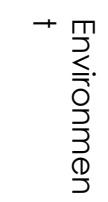 & $\begin{array}{l}\tilde{0} \\
\underline{\underline{\Lambda}} . \\
\underline{\underline{\alpha}}\end{array}$ & $\begin{array}{l}\text { ח1 } \\
\text { ก} \\
\frac{0}{3} \\
\frac{0}{3} \\
3\end{array}$ & 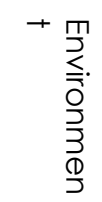 & & 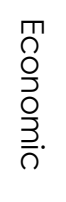 \\
\hline$\sqrt{ }$ & $\sqrt{ }$ & $\sqrt{ }$ & $\sqrt{ }$ & $\sqrt{ }$ & $\sqrt{ }$ & $\sqrt{ }$ & & $\sqrt{ }$ & & $\sqrt{ }$ & $\sqrt{ }$ \\
\hline
\end{tabular}

Table 5. Integration between Water and Soil Quality and Dimension of Sustainability.

Additionally, the designer should consider the items that are given below:

- Interconnected streets with friendly pedestrians and cyclists, to avoid cardependency for users;

- Suitable and enough garages and parking spaces;

- Providing seasonal strategy, lighting and furniture in sidewalks to encourage people for walking;

- Waste management and recycling bins;

- Use of recycling and renewable material;

- Utilization renewable and endless energy;

- Increase quality of parks and conservation of lands to define and connect neighborhoods and districts with highly sense of belonging
- Improve the fuel efficiency of public transportation, improved regulations due to construction environmentally friendly transportation systems.

\subsubsection{Physical Characteristics}

Urban and building form has impact influence on the quality of urban life that the suitable urban form will be achieved by providing strategic planning, socio-economic planning and making harmony between the built environment with local and regional environmental realities. Applied suitable form in our designing has deep effect on energy consumption and $\mathrm{CO}^{2}$ emission. Size of city and building is other physical characteristics to 
achieve the best balance of economies, measuring spatial accessibility, effect on intensity and scale of environmental elements (Atkinson, 1993). Optimum the size of building and cities influence on controlling population size, consumption level of primary resources, air pollution, decrease environmental degradation, rising human health and safety, conserving ecological factors, and urban efficiency. For example, Height of building is the other elements that the feature impacts on air quality, urban heat island, and safety. Controlling densification of build environment has high connected with different problems including infrastructure overload, overpopulation, congestion, air pollution, urban heat island, demand energy for cooling, health hazards, lack of public and green space and environmental degradation (Hardoy et al., 1990). In addition, excessive energy use and high carbon emission rates can be decreased by changing the urban structure to achieve sustainability by the restructuring of urban mobility systems and transport planning, and harmonization between the built environment and natural environment. Suitable urban structure is applied to create short journeys, easy access to environmentally and socially sustainable opportunities. Also, an appropriate urban structure provide 'concentrated decentralization' by improving architectural design, the use of mixed land use and intensification strategies. The consideration has deep influence on achieving energy savings, urban energy efficiency, better access to nature and green space, and social and aesthetic improvements.

\subsubsection{Cultural Characteristics}

According to Rapoport (1997), the way of life, human value and behaviors, culture, human activities, and religious are significant values to express identity of built environment. People come from different country can be distinguished or defined by their culture because culture have deep relationship with the individuals' lifestyle and their behavior. Culture firstly sustain the identity of people which bring sense of belonging for individuals, secondly culture is the fundamental element to design a place for living because it can control their behavior, thirdly, the vital role of culture is to give meaning to a place as a framework that the place becomes memorable for people (Rapoport, 1995). Unfortunately, after globalization the fundamental factor was ignored because of increase immigration so lack of identity and sense of belonging was occurred and the consequences caused many problems in cities. Therefore, designers understand that they should make a relationship between past with the current and future especially in historical and traditional environment where totally reflect the culture and identity of the settlements. Designer should be responsible in designing the built environment towards past, current and future generations. Contextual design is a major discussion between all designers to consider the visual, spatial characteristics and the local needs in designing our surrounding. Contextual design try to represent the sense of belonging and identity of our environment for local people also it focus on contemporary design to consider the aesthetical characteristics for stranger and future population. The design identifies the historical and cultural values, scale, proportion, balance, rhythm, details, orientation and sitting location in streetscape and cityscape. Distinctiveness, visual appropriateness, and attractiveness are created through considering cultural values by contextual design.

\subsubsection{Social Characteristics}

When the city provides social cohesion for different people and mix use land for health communication, social characteristics will be achieved. Social justice is a process of developing a community to provide through diversity and mixed use land where people share their values and challenges in equal opportunities. In order to create livable city with health communication, the most important characteristic is provision inclusive and accessible design. Accessible/ inclusive design attempts to support individual's requirement regardless their alibies. Also, mixed use land try to provide a place for all users with respect to their capabilities like their incomes (diversity). The width of trails, quality of pavements for making comfortable travelling, regular maintenance, inclusive facilities, safe environment, access to adjacent surfaces with different levels, free-barrier routes, and measuring the slope of gradient ground are the most important indicators should be considered to provide a comfortable access for all users with respect of their abilities. Moreover, social justice is the fundamental 
consideration for social characteristics that it will be provided throughout intensification of activities and using of mix use land. Mix use landing and densities of different activities provide diversity, flexibility and the level of urban vitality because the place can apply different use for various users with respect to their position, gender, race, income, ethnicity and lifestyle. Meanwhile, accessible, available and adequate infrastructure like transportation, parking spaces and connectivity of roads are able to improve social sustainability in the cities. Strong infrastructure promotes the level of individuals' satisfaction for participating and more communication. Moreover, settlement systems can achieve the sustainability goals throughout balanced integration of settlement systems with nature (Atkinson, 1992). For instance the system can provide easy access to green environments, the conservation of rural and agricultural land, spatial equity in infrastructure and service provision and the avoidance of the spatial displacement. Additionally, land use management control demand for residential units, improving rural land on the urban edge, and conserving green and open space (Mathey, 2000). Also density, proximity, mixed use, continuity, clustering, concentration, nuclearity, and centrality are the dimensions to manage an appropriate pattern of land use (Galster et al., 2001). The defined indicators improve social communication and inclusion in different scale for people.

\subsubsection{Economic Characteristics}

It is obvious that economic situation of the society has fundamental effect on designing outside and inside of built environment (Lang, 1994). Maclennan, and William (1990) mentioned that affordability is a controversial concern to give the standard level and quality to all persons with low/ middle incomes. Affordability is not creating a place with low quality however it tries to consider long time costs and standard quality level of life for all users. Architecture and urban designer have deep influence in providing affordability in different scale such as affordable housing, easy access or proximity to health center, employment, education, all services, and consideration energy cost in housing because everyone has equal right to use these necessities. Additionally, land marketing has caused many objectives for especially low income people. However, land capacity can balance the cost differences between land values and individual income, and unsustainable urban land market could have a highly harmful effect on urban sustainability. Also, passive solar heating system, natural cooling techniques and systems for natural lighting are three categorizes of passive solar systems to create comfortable temperature and decrease life cycle of cost (LCC).

\subsubsection{Technological Innovation}

The issue of technological revolution has been a major concern in urban development because technology can bring advantages and disadvantages for the cities. by improving technology, the industrial factories, mass production of machines and cars, increase urbanization and urban immigration promoted by technology that the mentioned consequence invite air, water and noise pollution in the towns. on the other hand, designer try to use the revolution in positive way for example, producing recycling material with high speed; use of endless energy instead of fuel such as P.V. panels; green public transportation and building; safe environment and eco-friendly environment. Therefore, the innovation not only provides many aesthetical considerations but also achieves all dimension of sustainability.

\subsubsection{Political Characteristics}

Governance and political consideration is the most important part to achieve the mentioned parameters by responsive legislation, strong management, steady supervision, economic responsibility like give fund for improving the quality of building, use of effective and relative communities, promotion of creative and nonconventional solution-making. The responsive legislation should control location, heights, scale, human's requirements in different scales because as it is mentioned by Elliott (1992), the regulation can improve or decline the quality of cities and built environment for their users. Local governance, authorities and political leaders should attempt to improve visual quality, urban health and vitality by responsive and various long-term services. The following Table (Table 6) summarizes all characteristics of the metapostmodern style and it has been mentioned to the significant points of each of indicators. 


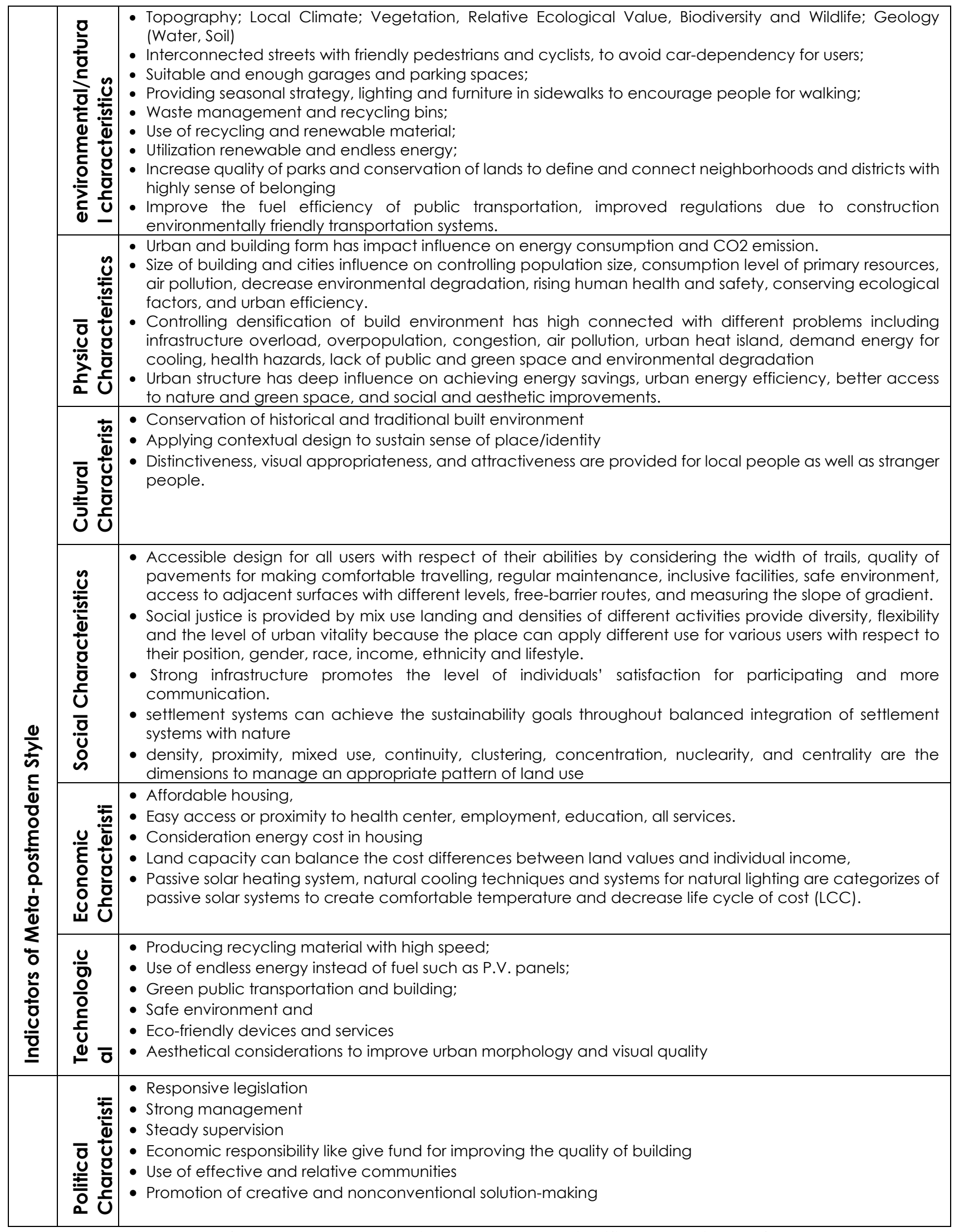

Table 6. Indicators of Meta-Postmodernism and the Significant Points of Each Mentioned Characteristics. 


\section{Conclusion}

Modern and postmodern styles cannot achieve individuals' satisfaction in all dimensions of human life. Although, each of styles tried to create some indicators, these styles ignored the other important characteristics. Homogenized city, building and lack of sense of belonging were the outcomes of modern architecture design. While, postmodernism try to survive sense of place, the style ignored future generation and diversity.

It is so obvious that all building and urban designers attempt to achieve the strategic sustainable planning for long-term vision. Therefore, the introduced style is considered the important indicators to achieve the high level of human life and users' satisfaction. Meta-postmodernism tries to provide a future construction with integrating past and current generations and they don't ignore the environmental characteristics. This study aims to consider the most significant indicators of meta-postmodern style as the fundamental indicators in order to sustain identity for local and future population and make attractive and memorable places for stranger people. As a result, the style improves livable city and health communication to support different generations under the use of these indicators and their important points. The considered indicators and their points have deep impact on introduced style and their importance has been considered and described. Considered indicators provide all dimensions of sustainability for different users with different characteristics. Therefore, the style improves the dimension of sustainability to achieve longterm planning. The style design is considered environmental/ natural, social, physical, economic, political, cultural and technological factors to achieve sustainable design with long-term decision-support and problemsolving for various people. Applying the indicators of meta-postmodernism not only, respects to various people with different race, position, gender, and ethnicity without compromising future requirements but also, it can provide visual quality or aesthetical considerations for present and future generations. Thus, the style improves the standard level of human life for all. This research reveals that parameters and indicators that have direct effect on urban vitality and urban guilty life for all which are the main factors for the style. Consequently, the research introduced the style and their indictors to improve awareness and reduce limitations in existing styles of design.

\section{Acknowledgment}

I would like to express my sincere thanks to Assist. Prof. Dr. Nazife Özay for her helpful critics and technical coordination during the study on this research. This research did not receive any specific grant from funding agencies in the public, commercial, or non-for-profit sectors.

\section{References}

Able, C. (1997) Architecture and identity. Towards a global eco-culture, Architectural Press, Oxford.

Atkinson, A. (1992) The urban bioregion as 'sustainable development' paradigm. Third World Planning Review 14 (4): 327-354.

Beer, A. R. and Higgins, C. (2000) Environmental Planning for Site Development: A manual for sustainable local planning and design, Taylor \& Francis Group, New York.

Calinescu, M., (1987) Five Faces of Modernity: Modernism, Avant-garde, Decadence, Kitsch, Postmodernism. USA: Duke University Press.

Courtney, F.M. and Trudgill, S.T. (1984) The Soil, an Introduction to Soil Study, Edward Arnold: London.

Galster, G. and Hanson R., Ratcliffe, M.R., Wolman, H., Coleman, S., and Freihage, J. (2001) Wrestling sprawl to the ground: defining and measuring an elusive concept. Hous Policy Debate 1.

Hardoy, J.E. and Cairncross, S. and Satterthwaite, D. (1990) The Poor Die Young: Housing and Health in Third World Cities, Earthscan: London.

Harvey, D. (1989) From managerialism to entrepreneurialism: the transformation of urban governance in late capitalism, Geografika Annaler.

Harvey, D. (1993) From space to place and back again: reflections on the condition of postmodernity, in: Bird, J., Curtis, B., Putnam, T., Robertson, G., \& L. Tickner, L., Mapping the Futures: Local Cultures, Global Change (London, Routledge).

Heynen, H., and Henket, H.J. (2002) Back from Utopia. Rotterdam, The Netherlands: Uitgeverij 010 Publishers.

Lang, J. (1994) Urban Design: The American Experience, Van Nostrand Reinhold: New York. 
Laurie, I., (1979) Nature in Cities: the Natural Environment in the Design and Development of Urban Green Space: Wiley, Chichester.

Maclennan, D. and Williams, R. (1990) Affordable Housing in Britain and America. York: Joseph Rowntree Foundation.

Mathey, K. (2000) Urban agriculture, Trialog 65: A Journal for Planning and Building in the Third World: Special Issue, 2(5).

Mokhtarshahi, R. (2009) An Inquiry into Iranian Architecture Manifestation of Identity, Symbolism, and Power in the Safavid's Public Buildings, Published Ph.D. Thesis, Eastern Mediterranean University, Gazimagusa, Cyprus.

Morgan, M. (1914) Vitruvius: The ten books on architecture. Cambridge, MA: Harvard University Press.

Newman, P. (2002) Sustainability and housing: More than a roof over head, Paper presented at the 2002 Barnett Oration, Melbourne, 31st October.

Ozay, N. (2005) A comparative study of climatically responsive house design at various periods of Northern Cyprus architecture. Elsevier, Building and Environment.

Rapoport, A. (1995) Culture, site layout and housing. In A. Rapoport, Thirty three papers in environment-behavior research. Newcastle (UK): Urban International Press.

Rapoport, A. (1977) Human Aspect of Urban Form Wheaton \& Co Ltd., Exeter.

Schoon, I. (1992) Creative achievement in architecture: A psychological study. Leiden University: DSWO Press.

World Commission on Environment and Development, (WCED, 1987), "Our Common Future". Retrieved 2 Nov, 2009 from, http:// en.wikipedia.org/wiki/Our_Common_Future URL 1: Zigzag around the world. (2014) Amman: The Ugly and The Beautiful, www.zigzagging.net 